\title{
The critical role of open space in hazard mitigation (earthquake) in traditional commercial spaces: a case study - Qazvin Old Bazaar
}

\author{
H. Sadat Nabavi Razavi \\ Department of Reconstruction, Shahid Beheshty University, Tehran, Iran
}

\begin{abstract}
Disasters, whether caused by humans or nature, impose significant threats to sustainability. Reducing vulnerability to natural disasters is an essential component of achieving sustainable cities. Most cities suffer from severe damage caused by natural disasters like earthquakes. Qazvin is a historical city in Iran with an important commercial role. It lies in a most hazardous prone area in the country with respect to earthquake. During its history Qazvin has faced different earthquakes which had drastic impacts on the most historical parts of the city such as the Old Bazaar as a main economic center in the country.

Qazvin Old Bazaar has undergone development for centuries. There are many historical monuments and landscape-conservation areas in Qazvin. Dense old buildings and narrow covered passage networks exist in the Old Bazaar, recent rapid urbanization and using modern urban elements in this area have been leading into changing the most vulnerable areas. Hazard Mitigation Plans are needed to reduce the loss of life and property by lessening the impacts of disasters (natural, technological and man-made) to reach safe trade center and finally sustainable city to live.

This paper aims to analyze the issues related to physical urban vulnerability in detail to arrive at strategies or policy based solutions that are necessary to support the redevelopment of urban areas like Qazvin Old Bazaar. By combining this vulnerability assessment of Qazvin Old Bazaar, this paper tries to give some strategic guidelines for the utmost use of open spaces during disaster and
\end{abstract}


ordinary times. Measures to control vulnerability, in particular the use of low density development, and surrounding open space in densely populated urban areas are suggested.

Keywords: hazard mitigation, Qazvin Old Bazaar, open spaces, historical cities.

\section{Introduction}

The purpose of hazard mitigation is to reduce or eliminate the long-term risk to human life and property from natural, human-caused and technological hazards and their aftermath effects. Examples of mitigation actions include structural retrofit to reduce potential damage from earthquakes or having special plan for emergency phase in disaster which prevent chaos and confusion in public and crowded urban spaces (Allan and Bryant [1]).

In the search for appropriate instruments for mitigating hazards, research projects in recent decades have called for a shift in focus from hazards response and recovery to proactive measures to mitigate the effects of natural hazards on humans. Hazards mitigation has traditionally referred to measures that can be taken to minimize the destructive and disruptive effects of hazards and thus lessen the magnitude of a disaster. Mitigation measures can take a variety of forms, ranging from physical or structural measures, to controlling development in hazardous areas through land use planning and policy-making. Efforts during recent decades have largely been focused on physical or structural mitigation measures. Experience has proven time and again that these types of measures alone are inadequate.

The concept of sustainable hazard mitigation has then evolved and been refined over the last half-century (Tsinda and Gakuba [4]). Integration of hazard mitigation as an integral part of participatory process, environmental quality improvement and disaster resiliency is considered essential to achieving hazards mitigation and finally sustainability. Hence, the purpose of this paper is to apply the literature relevant to hazards mitigation into the context of Qazvin Old Bazaar.

\section{The bazaar and its character in Iranian typical cities}

Urban sociologists, urban planners and designers generally explain the bazaar as the heart of the Iranian city. In socio-economical level; although the main part of the famous bazaar is formed by retail, the bazaar is not entirely a retail cluster. The Persian bazaar is a unified, self-contained building complex of shops, passageways, and caravanserais, interspersed with square (Meydan), religious buildings, bathhouses (Hammam), and other public in- situation”. The Friday mosque, which is the main religious and political centre of the city, and the bazaar always found together. Therefore, the Friday mosque is sometimes located next to or part of the bazaar. Moreover, the bazaar is the place to celebrate important political events, or refusing to celebrate such events to express political disagreement (Masoudi Nejad [5]). Simply speaking, the bazaar is not only the main socio-economic center, but also is unsurprisingly the main 
spatial structure of the Iranian city. Therefore, bazaars have an important role in having sustainable city and it needs to stay intact during earthquake and should respond to inhabitant s requirements such as safe place against disasters.

\section{The city of Qazvin and its old bazaar}

Qazvin, the center of the province of Qazvin, is situated in the North West of Iran. Qazvin is known as one of the most ancient regions in Iran. It is located on the Silk Road among 3 economic poles, Hamadan, Rey and Tabriz. When Qazvin was chosen as capital of Iran in the Safavid era, its location for trade was great and its historical bazaar has gained its important role in the whole of the life of the city (Golriz [3]). Figure 1 shows Qazvin Old Bazaar in the central part of the city.

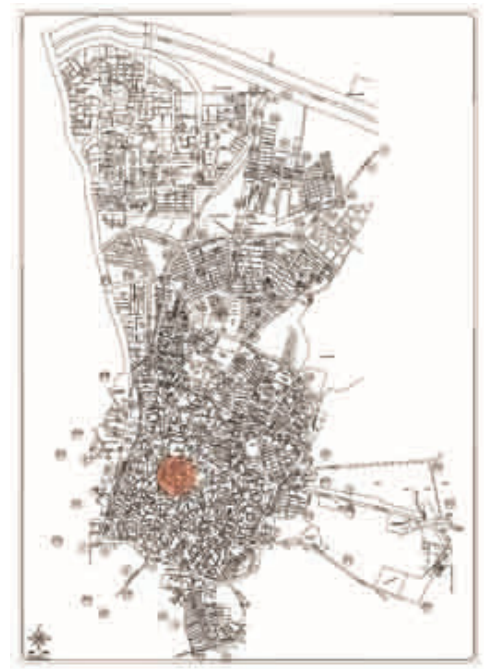

Figure 1: Map of the old bazaar district (pink circle) in Qazvin City (source: Qazvin Municipality).

Admittedly, Qazvin is one of the most important seismic areas in Iran and even the world for its special geological structure and existence of more active faults, more than 10 historical earthquakes happened in this area and they caused massive destruction on infrastructures, urban spaces and numerous death tolls. Figure 2 portrays all faults which are around Qazvin.

\section{Qazvin Old Bazaar and its problems}

In recent years, it has become apparent that the vulnerability to hazards of urban areas such as Qazvin Old Bazaar has increased with the wide spread of infrastructures which brings more harm than benefits such as gas and electricity line networks in a non-standard way, different varieties of land use which are not 


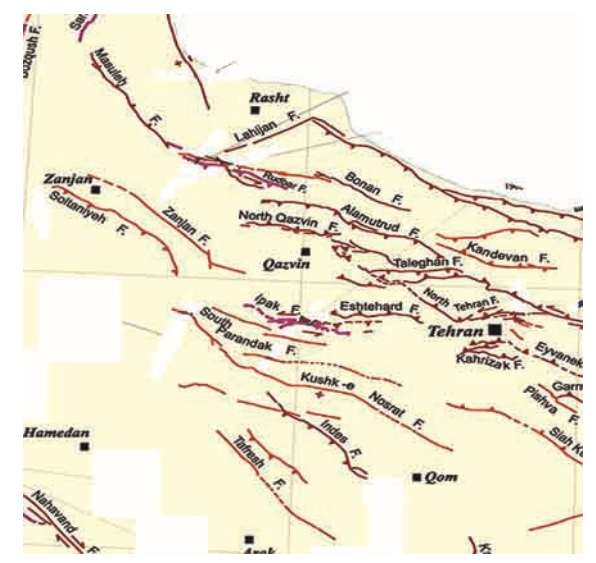

Figure 2: Map of faults in Qazvin region (source: International Research Center of Seismology).

congruent and the rapid growth of a high-density population and they are becoming more dangerous with exposing to disasters. As major factors which influence the fragility of urban areas such as the old bazaar against disasters are considered in Figures 3 and 4.

- Mixture of old and new buildings and facilities with different level of seismic performance brings regional seismic potential.

- Lack of resistant structure in front of earthquakes in Historical Old Bazaar

- Narrow networks and roads with poor conditions which have interfered with emergency performance during disasters and public services could be interrupted beyond their limits.

- High-density population increases the danger of human life losses.

- Concentration of important functions of public institutions and private sectors brings long-term disruption to the daily life.
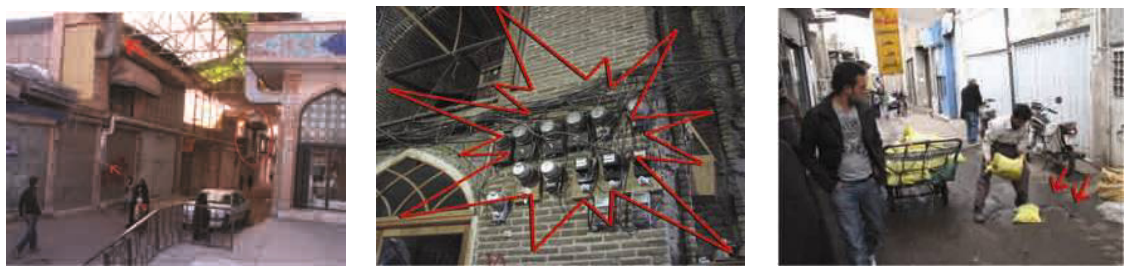

Figure 3: Some problems in the Qazvin region such as non standard gas line, electricity network and poor condition in networks (author). 

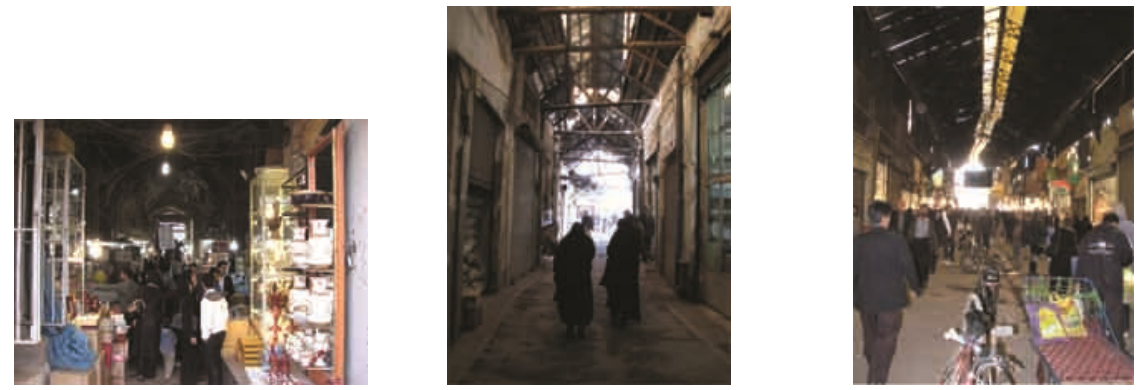

Figure 4: $\quad$ Some problems in the Qazvin region such as crowded road, lack of resistant structure of bazaar's roof and access intervention between pedestrian and motorcycles.

These factors bring more vulnerability to the Old Bazaar. Furthermore, other factors like lack of remedial centers and hospitals in the Bazaar region, inefficiency of fire hydrants, lack of emergency planning, lack of proper organization of spaces and so on aggravate the bazaar's condition in front of disasters.

\section{Hazard mitigation and the role of open spaces in dense fabrics}

Documented responses to earthquakes from around the world suggest that ample and adaptable amounts of open space surrounding buildings are of enormous value both during and after an earthquake event. Open space becomes a refuge for, and a temporary home to thousands of people who need to quickly adapt to their new environment for days, months or even years. After a major earthquake, the open space network becomes a kind of 'second city', providing multiple complex functions such as gathering and shelter, the distribution of goods and services, the re-establishment of commerce, temporary inhabitation, commemoration, and the storage of contaminated or hazardous materials. The network becomes charged with new meaning; its spaces and their components are re-assessed for their capacity to support survival and recovery (Blaikie et al. [6]).

It means that in all urban areas with high dense, open spaces can be useful during hazards and aftermath. In Bazaar spaces, there are a lot of open spaces with different land use such as Caravansaries, Barf-Andaz (places for stockpiling snow to prevent damage of snow weight and damp to roofs during winter). Some of these spaces have lost their roles nowadays and they are unused and shop keepers occupy them illegally, while they can be used as open spaces with multifunctions.

The Bazaar is a crowded space during daytime and many people go there to get what they need. Necessity of a hazard mitigation plan is clear and open spaces should be redesigned for disasters. 


\section{Research methodology}

This paper is based on the results of a research project that was conducted by the author as her dissertation for getting her MA degree in reconstruction after disaster recently. The research project which was held by the author was done within a mix of qualitative as well as quantitative approach. A survey was conducted by interviewing both shop keepers as well as customers who go to the bazaar frequently. The results of these interviews, alongside the results of literature reviews and longtime observations, were analyzed together to form up the research outcomes.

\section{Results and analysis}

In summary, historical tissues suffer from inappropriate roads and networks, dense and complex urban tissues, low quality urban facilities and equipment, their location in downtown, lack of relief center in the bazaar tissues, etc. Figure 5 shows the commercial and residential part of Qazvin Old Bazaar.

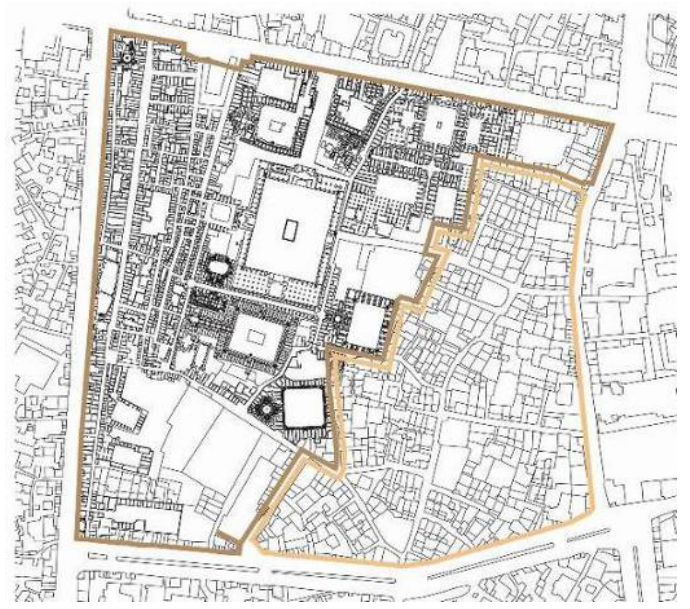

Figure 5: Qazvin Old Bazaar (the area which is surrounded by a dark line) and the residential area (surrounded by a light line).

In this research, the SWOT technique was used in order to investigate and compare the strengths, weaknesses, opportunities and threats to achieve important criteria appropriate approaches toward the best policies and conditions which were produced by strengthening positive points and reducing the negative ones.

- Strengths: characteristics of the urban spaces that give it an advantage over other spaces.

- Weaknesses (or limitations): are characteristics that place the urban spaces at a disadvantageous position. 
○ Opportunities: external chances to improve performance (e.g. make greater profits) in it.

- Threats: external elements in the urban paces that could cause trouble for them.

\subsection{Strengths}

- Qazvin Old Bazaar is one of the important economic poles of the country. It should remain safe for having a sustainable economy and a sustainable city (Varjavand [7]).

- Construction of Qazvin Old Bazaar date backs to the Safavid era and it has valuable historical buildings.

- Qazvin Old Bazaar is not only the main commercial center of the city but also it plays a social and cultural role for Qazvininan inhabitants.

\subsection{Weaknesses}

- Severe destruction in historical parts of the Bazaar.

- Lack of suitable urban infrastructures.

- Lack of monitoring and suitable control systems.

- Lack of appropriate risk management and alert risk systems.

- Non-resistant structures which cannot resist in disasters.

- The narrow width of road networks in the Bazaar.

- Overcrowding in some hours and some seasons aggravate the condition.

- Lack of a hazard mitigation plan.

- Lack of open spaces which are to be considered a safe place for evacuation of people in disasters.

\subsection{Opportunities}

- Open spaces which don't have any can be used in order to reorganization of bazaar

- Demands of shop keepers to have a safe place for trade;

- People like the Bazaar as a memorial space and they like to preserve it against disasters;

- High capacity for tourism development;

- Using open spaces as multi-function spaces for parking, remedial centers and as a place for evacuation in emergency time. Figures 6-8 show the appropriate open spaces without important land use.

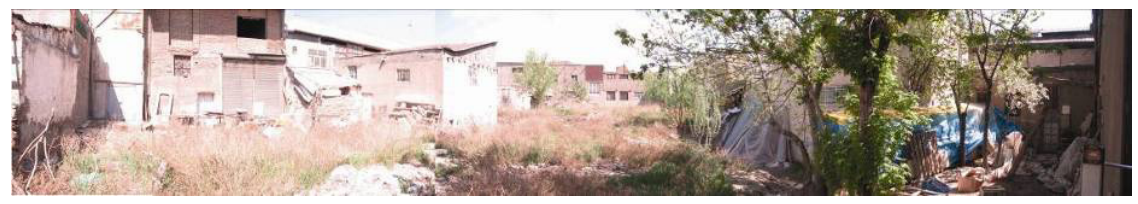

Figure 6: $\quad$ Open spaces with no land use. 


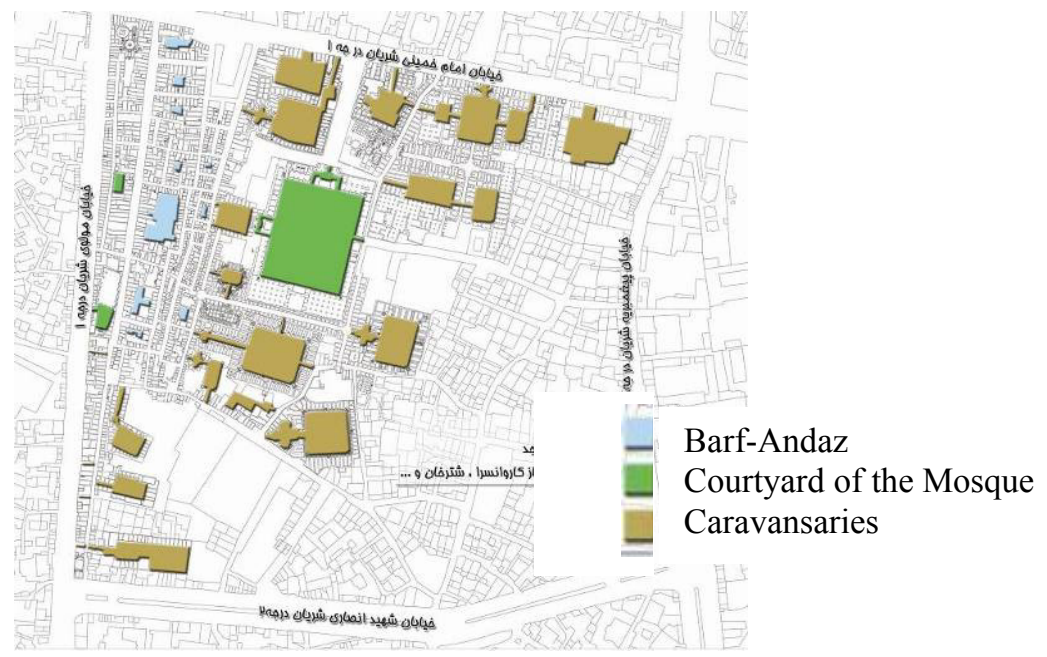

Figure 7: Open spaces in Qazvin Old Bazaar.

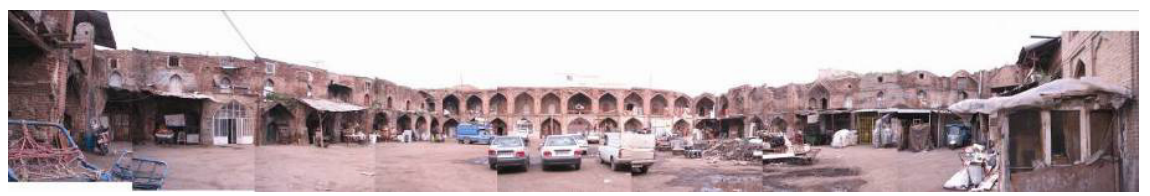

Figure 8: $\quad$ Open spaces which are used by shopkeepers as their own territory.

\subsection{Threats}

- Continuance of disorganization of the main tissue in the urban areas;

- Continuance of deterioration process in the historical parts surrounding the bazaar;

- High cost of restoration and insurance, especially at commercial parts of the area;

- Lack of management quality is discouraging people from proper participation;

- Willingness of people to demolish the old and build new commercial centers, instead of restoration in the traditional style;

- Public desire for enlarging access routes which may damage the whole structure of the area.

Based on observation and survey which was conducted on bazaar mitigation plans, the road with high probability of risk were clarify. This analysis was conducted by using Space Syntax model and Table 1 shows the results. The term space syntax encompasses a set of theories and techniques for the analysis of spatial configurations. Originally it was conceived by Bill Hillier, Julienne Hanson and it helps to have better understanding on urban spaces and networks. 
Table 1: $\quad$ Analysis of Qazvin Old Bazaar plan based on space syntax model (R2: second level access according to population density; R3: third level access according to population density, I\&S: score of importance degree and safety).

\begin{tabular}{|c|c|c|c|c|c|}
\hline & & $\mathbf{R 2}$ & R3 & I\&S & Plan \\
\hline 1 & Ahangarha Raste & 7 & $*$ & high & \\
\hline 2 & Allafha Raste & 8 & 3 & Very high & \\
\hline 3 & Dabaghha Raste & 3 & * & low & \\
\hline 4 & $\begin{array}{l}\text { Gerd } \\
\text { bazaar }\end{array}$ & 5 & * & medium & \\
\hline 5 & Gharbalsaz Raste & 4 & 1 & medium & \\
\hline 6 & Halabisaz Raste & 7 & * & High & \\
\hline 7 & Halaj Raste & 6 & 2 & High & \\
\hline 8 & Kafashha Raste & 7 & * & High & \\
\hline 9 & Lavaf Raste & 8 & 2 & Very high & \\
\hline 10 & Najar Raste & 6 & * & High & \\
\hline 11 & Risman sanj & 9 & 2 & Very high & \\
\hline
\end{tabular}


Table 1: $\quad$ Continued.

\begin{tabular}{|l|l|l|l|l|l|}
\hline & & R2 & R3 & I\&S & \\
\hline 12 & Shykholslam Ghysariye & 6 & 1 & High & \\
\hline 13 & Zargar Raste & 8 & $*$ & High & \\
\hline 14 & Bazaz Raste & 9 & 2 & Very high & \\
\hline
\end{tabular}

Each crowded road was considered based on the number of second and third level of access which guides the population to them. According to this technique, it can be easier to find out a score of importance degree and safety.

Table 2 reveals that some rastes (main roads in the Bazaar which have many stores in them) need to be considered as critical spaces because they are heavily crowded. They can cause a lot of damage to people and their capital due to the fact that there are no designed spaces for evacuation at times of emergency. Based on the table the importance of rates are as follows, and they need immediate management planning for hazard mitigation.

Table 2: Qazvin Old Bazaar rastes' importance respectively and their needs for reorganization.

\begin{tabular}{|l|l|l|l|}
\hline 1 & Bazaz Raste & 8 & Shykholslam Ghysariye \\
\hline 2 & Allafha Raste & 9 & Halabisaz Raste \\
\hline 3 & Lavaf Raste & 10 & Ahangarha Raste \\
\hline 4 & Risman sanj & 11 & Najar Raste \\
\hline 5 & Zargar Raste & 12 & Gerd bazaar \\
\hline 6 & Halaj Raste & 13 & Gharbalsaz Raste \\
\hline 7 & Kafashha Raste & 14 & Dabaghha Raste \\
\hline
\end{tabular}

To successfully plan, using open spaces in the Bazaar is an important step towards a mitigation plan. Three functions are offered to these useful spaces:

1. In ordinary times, some of these spaces can be used as parking spaces. They can create income from hiring parking spaces to bazaar users. These revenues can be used for the hazard mitigation plan. 
2. Other open spaces can be equipped with remedial devices for an urgent situation.

3. Evacuation roads should be clarified and they should not be closed in emergency time due to the fact that they are used as safe roads in disasters.

Figure 9 shows the proposed plan for open spaces in the Bazaar and Figure 10 shows the proposed plan for hazard mitigation in Qazvin Old Bazaar.
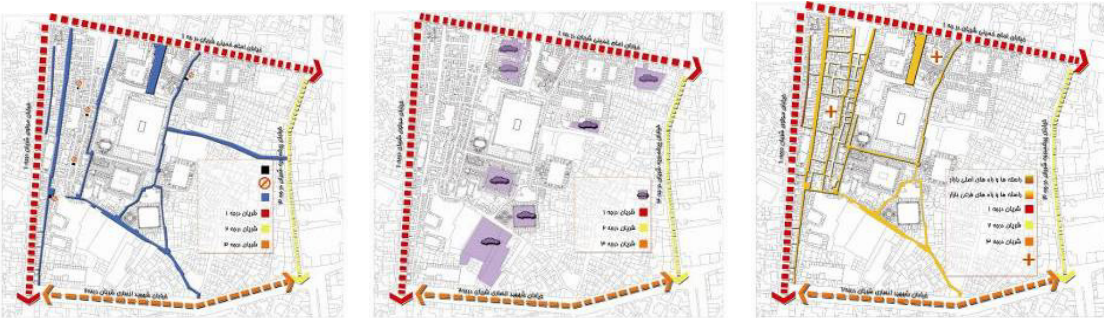

Figure 9: $\quad$ Proposed plan for open spaces in Qazvin Old Bazaar, (left plan: evacuation roads are colored blue; middle plan: proposed parking spaces; right plan: the proposed remedial centers).

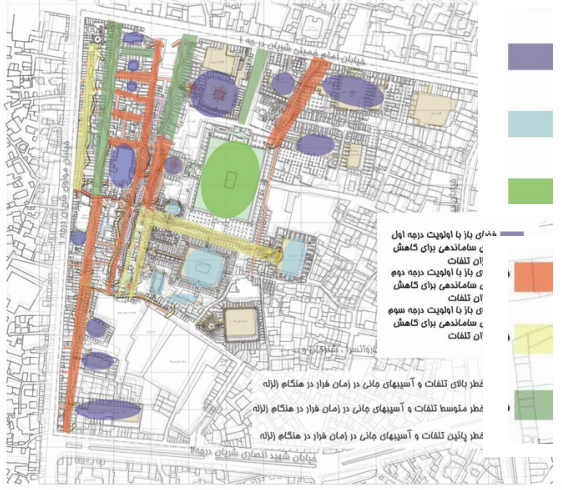

Open spaces with high priority of reorganization for evacuation Open spaces with medium priority of reorganization for evacuation Open spaces with low priority of reorganization for evacuation Roads with high risk of casualties at emergency time Roads with medium risk of casualties at emergency time Roads with low risk of casualties at emergency time

Figure 10: The proposed plan for hazard mitigation (the priority of reorganization in open spaces and emergency roads).

\section{Conclusions}

All the evidence suggests that the intensity of some hazards (extreme earthquakes) and the vulnerability of human communities to natural disasters are increasing. This means that there are more natural hazards and also that a larger proportion of these hazards develop into serious disasters. 
The economic and human costs are rising sharply, so society needs increased investment in disaster prevention and relief. In general, for having sustainable community and city against disasters (Tsinda and Gakuba [8]):

- Legislation should provide an adequate framework for conservation management;

- The Bazaar needs comprehensive management plans, and they should fully implemented;

- Local communities rarely have any role in the management of their commercial spaces resulting in the fact that they never accept plans which are prepared for them; considering them as troublesome rules. Consequently, they should be accepted as an important part of a hazard mitigation plan.

- Zoning is a helpful policy to control access to high risk areas. It is better to divide the Bazaar region into different zones to have better monitoring and hazard mitigation.

\section{References}

[1] Allan P. and Bryant M. "The Critical Role of Open Space in Earthquake Recovery: A Case Study" University of Wellington, Wellington, New Zealand.

[2] Berberyan, M. and Ghoreyshi, M. Seismotcetonic and earthquake - fault hazard investigations in the greater Qazvin region. Geology survey of Iran, Tehran No: 61, 1993.

[3] Golriz, M. A. Minoodar or Bab aljanat. Tehran. Taha publication. 1959.

[4] Tsinda, A. and Gakuba, A. Sustainable Hazards Mitigation in Kigali City (Rwanda), 46th ISOCARP Congress, 2010.

[5] Masoudi Nejad, Reza. "Social Bazaar and Commercial Bazaar: Comparative Study of Spatial Role of Iranian Bazaar in the Historical Cities in Different Socio-economical Context" Proceedings of 5th International Space Syntax Symposium, Vol. 1, 197-200, 2005.

[6] Blaikie, P., Cannon, T., Davis, I. and Wisner, B. At Risk: natural hazards, people's vulnerability, and disasters. New York: Routledge, 1994.

[7] Varjavand, P. Simaye tarikh va farhange Qazvin. Ney Publication, 1999.

[8] Tsinda, A. and Gakuba, A. Sustainable Hazard Mitigation in Kigali City (Rwanda), Workshop 4, 2010. 